\title{
Effects of four organic pollutants on the growth of natural marine bacterioplankton populations
}

\author{
John P. Hudak*, Jed A. Fuhrman** \\ Marine Sciences Research Center, S.U.N.Y. at Stony Brook, Stony Brook, New York 11794-5000, USA
}

\begin{abstract}
Acute and long-term toxicities of 2 low molecular weight polycyclic aromatic hydrocarbons (PAHs) and 2 organochlorine pesticides on bacterial growth were assessed, using incorporation of tritiated thymidine $\left(\left[^{3} \mathrm{H}\right] \mathrm{TdR}\right)$ into bacterial cell macromolecules as growth indicator of natural populations of coastal bacterioplankton. Acute toxicity of the 4 compounds increased in the following order: naphthalene $<$ phenanthrene $<$ Kepone $=$ pentachlorophenol (PCP), the minimum significantly inhibiting concentrations $(p<0.05)$ being $1 \mathrm{mg} \mathrm{I}^{-1}, 100 \mu \mathrm{gl}^{-1}, 100 \mathrm{\mu g} \mathrm{l}^{-1}$, and $10 \mu \mathrm{gl}^{-1}$, respectively. Comparisons with a past study on sediment microorganisms from a salt marsh near the sampling site (near New York, USA) used here indicate that bacterioplankton are more susceptible to organic pollutants than are sediment bacteria. In the long-term studies, total bacterioplankton activity recovered from $10 \mathrm{mg} \mathrm{l^{-1 }}$ naphthalene, $100 \mu \mathrm{gl}^{-1}$ phenanthrene, and $1 \mathrm{mg} \mathrm{l}^{-1}$ Kepone after $1 \mathrm{~d}$, whereas recovery from $1 \mathrm{mg} \mathrm{l}^{-1}$ PCP required $3 \mathrm{~d}$. Recovery could have been due to adaptation of individuals or selective growth of resistant bacteria. Some of the population effects we observed could have been due to toxic effects on eukaryotic grazers that usually keep bacterial populations in check. It is concluded that of the 4 pollutants studied, PCP poses the greatest potential threat to marine bacterioplankton populations.
\end{abstract}

\section{INTRODUCTION}

Use of petroleum products and pesticides worldwide has resulted in large organic pollutant inputs to coastal waters (Huggett \& Bender 1980, Connell 1982, Hoffman et al. 1984, Brown et al. 1985). Research findings over the past decade indicate that bacteria make a significant contribution to the marine planktonic food web through the recycling of dissolved organic matter and by serving as prey for heterotrophic protozoa (Hagström et al. 1979, Williams 1981, Fenchel 1982, Fuhrman \& Azam 1982, Ducklow 1983, Fuhrman \& McManus 1984). Susceptibility of marine bacterioplankton to organic pollutant inputs could alter the efficiency of the above processes, upsetting important interactions among bacteria, bacteriovores, and phytoplankton which serve to cycle nutrients and energy throughout microbial food webs.

Most pollutant toxicity studies in the past concerning

\footnotetext{
- Present address: South Central Connecticut Regional Water Authority, 90 Sargent Drive, New Haven, Connecticut 06511-5966, USA

- Addressee for correspondence
}

aquatic bacteria have used either the growth of laboratory cultures (Walker \& Colwell 1975, Calder \& Lader 1976, Blakemore \& Carey 1978, Mahaffey et al. 1982) or heterotrophic potential techniques, such as radiolabeled glucose or glutamate uptake (Sayler et al. 1979, Alexander \& Schwarz 1980, Griffiths et al. 1981) as indicators of pollutant effects. In the present study we examined the acute and longer-term effects of naphthalene, phenanthrene, Kepone (decachlorooctahydro-1,3,4-metheno-2H-cyclobuta[cd]-pentalen2-one), and pentachlorophenol (PCP) on the growth of natural bacterioplankton assemblages, as estimated by the incorporation of [methyl- $\left.{ }^{3} \mathrm{H}\right]$ thymidine $\left(\left[{ }^{3} \mathrm{H}\right] \mathrm{TdR}\right)$. Naphthalene and phenanthrene are low molecular weight polycyclic aromatic hydrocarbons (PAHs), whereas Kepone and PCP represent 2 organochlorine pesticides. This method provides a more realistic approach to assessing the effects of pollutants than culture methods because only 0.01 to $10 \%$ of marine bacterioplankton are viable on nutrient media (Jannasch \& Jones 1959, Meyer-Reil 1977, Ferguson et al. 1984). In addition, $\left[{ }^{3} \mathrm{H}\right] \mathrm{TdR}$ incorporation has been shown to be a more sensitive toxicity indicator than either $\left[{ }^{14} \mathrm{C}\right.$ ]glutamate or $\left[{ }^{14} \mathrm{C}\right.$ ]glucose uptake (Jonas et al. 1984, Bauer \& Capone 1985) 


\section{MATERIALS AND METHODS}

All seawater samples for this study were obtained off a pebble beach at Crane Neck Point, New York, USA $\left(40^{\circ} 55.3^{\prime} \mathrm{N}, 73^{\circ} 09.3^{\prime} \mathrm{W}\right)$. Crane Neck overlooks a relatively pristine area of Long Island Sound, with no industry or harbors in the immediate vicinity. Samples were collected in acid washed plastic sampling bottles or carboys, and returned immediately to the lab under simulated in situ conditions. All glassware used was acid washed and rinsed twice with seawater before experiments were conducted.

Pollutants used were naphthalene and phenanthrene (Eastman Kodak Co., Rochester, NY, USA), Kepone (Chem Services Inc., West Chester, Pa., USA), PCP (Alldrich Chemical Co., Milwaukee, Wis., USA) $\left[1,(4,5,8)-{ }^{14} \mathrm{C}\right.$ ]naphthalene, $5 \mathrm{mCi} \mathrm{mmol}{ }^{-1}$ (Amersham Corp., Arlington Heights, Ill., USA), $\left[9-{ }^{14} \mathrm{Clphenan-}\right.$ threne, $\quad 21.5 \mathrm{mCi} \mathrm{mmol}^{-1}, \quad\left[{ }^{14} \mathrm{C}\right] \mathrm{Kepone}, \quad 8.07 \mathrm{mCi}$ $\mathrm{mmol}^{-1}$, and $\left[\mathrm{U}^{14} \mathrm{C}\right.$ ]pentachlorophenol, $10.57 \mathrm{mCi}$ $\mathrm{mmol}^{-1}$ (Pathfinder Laboratories Inc., St Louis, Mo., USA).

Acute effects experiments were conducted during a $1 \mathrm{wk}$ period in May 1985, with each pollutant tested on a separate day. Of freshly collected seawater $20 \mathrm{ml}$ were dispensed into triplicate clean, sterile $50 \mathrm{ml}$ plastic centrifuge tubes at each pollutant concentration (see 'Results' for concentrations added). All concentrations were below the solubility for each compound, which are $32,1.3,2$ to 4 , and $4 \mathrm{mg} \mathrm{l}^{-1}$ for naphthalene, phenanthrene, Kepone, and PCP, respectively (Meyling \& Pitchford 1966, Verschueren 1983, Dzombak \& Luthy 1984). Pollutants were added via syringe in $5 \mu \mathrm{l}$ of acetone. Triplicate controls received $5 \mu$ l of acetone. Duplicate killed controls received $0.2 \mathrm{ml}$ boratebuffered formalin. Of the original sample $10 \mathrm{ml}$ were preserved with $5 \%$ borate buffered formalin for later bacterial enumeration. Experimental samples were acclimated for $45 \mathrm{~min}$ in a lighted (ca $100 \mu \mathrm{E} \mathrm{m}^{-2} \mathrm{~s}^{-1}$ ) incubator set at $13^{\circ} \mathrm{C}$, before starting $\left[{ }^{3} \mathrm{H}\right] \mathrm{TdR}$ measurements as described below.

Long-term experiments ( 2 to $7 \mathrm{~d}$ ) were carried out from December 1984 through February 1985. Each of the 4 compounds was studied in separate experiments. Samples $(200 \mathrm{ml})$ of freshly collected seawater were dispensed into triplicate $250 \mathrm{ml}$ flasks for each pollutant concentration (see 'Results' for concentrations). A trace amount of ${ }^{14} \mathrm{C}$-labeled pollutant was added to each flask containing pollutants to monitor loss (e.g. by evaporation) over the course of the experiment. Pollutants were added in acetone carrier and controls received acetone alone. The highest concentration of acetone used in any of the experiments in this entire study was $300 \mu \mathrm{l}^{-1}$ In a separate experiment this concentration of acetone was not found to result in a significant alteration of $\left[{ }^{3} \mathrm{H}\right] \mathrm{TdR}$ incorporation when compared to untreated seawater samples $(p>0.5, n=4$ replicates). In addition to the control and pollutant treatments, triplicate killed controls $(1 \%$ borate buffered-formalin) were used to correct for any abiotic adsorption of $\left[{ }^{3} \mathrm{H}\right] \mathrm{TdR}$. Two $\mathrm{ml}$ samples from each flask were pipetted into $20 \mathrm{ml}$ glass scintillation vials containing $5 \mathrm{ml}$ of NEN 963 scintillation cocktail (New England Nuclear Corp., Boston, Mass.) for measurement of initial ${ }^{14} \mathrm{C}$-pollutant concentrations by liquid scintillation. Following sample preparation, all flasks were capped with butyl rubber stoppers and transferred to a rotary shaker set at $50 \mathrm{rpm}$ and situated in a $20^{\circ} \mathrm{C}$ coldroom on a $12 \mathrm{~h}$ light-dark cycle.

Preliminary experiments using $200 \mathrm{ml}$ of autoclaved and filter-sterilized seawater indicated that after $24 \mathrm{~h}$ ca $50 \%$ of initially added $\left[{ }^{14} \mathrm{C}\right.$ )naphthalene had disappeared from the water, probably due to volatilization. Similar experiments demonstrated a $30 \%$ loss in $\left[{ }^{14} \mathrm{C}\right]$ phenanthrene radioactivity after $3 \mathrm{~d}$ and that ${ }^{14} \mathrm{C}$ label associated with PCP and Kepone remained virtually at initial levels for $7 \mathrm{~d}$. On the basis of this information, long-term effects experiments with naphthalene and phenanthrene were run for 2.2 and $3.2 \mathrm{~d}$ respectively, while the PCP and Kepone studies were terminated after $7 \mathrm{~d}$. At selected time-points the following subsamples were withdrawn by pipet from each flask: $2 \mathrm{ml}$ added to $5 \mathrm{ml}$ NEN 963 scintillation cocktail, in which ${ }^{14} \mathrm{C}$-pollutant radioactivity was measured by liquid scintillation; $5 \mathrm{ml}$ preserved with $5 \%$ boratebuffered formalin for later bacterial enumeration; $5 \mathrm{ml}$ put into clean, sterile $50 \mathrm{ml}$ plastic centrifuge tubes for $\left[{ }^{3} \mathrm{H}\right] \mathrm{TdR}$ incorporation.

Incorporation of $\left[{ }^{3} \mathrm{H}\right] \mathrm{TdR}$ into TCA-insoluble material (primarily DNA along with some RNA and protein) was assessed following the methods of Fuhrman \& Azam (1982). Samples from pollutant toxicity experiments were incubated for 30 min with $5 \mathrm{nM}\left[{ }^{3} \mathrm{H}\right] \mathrm{TdR}$ (New England Nuclear Corp., Boston, Mass., USA). The incubations were terminated by adding an equal volume of cold $10 \%$ trichloroacetic acid (TCA) $(5 \mathrm{ml}$ for long-term experiments, $20 \mathrm{ml}$ for acute toxicity tests). After $10 \mathrm{~min}$ of extraction in an ice bath, cold TCA insoluble material was filtered onto a $25 \mathrm{~mm}$ diam. $0.45 \mu \mathrm{m}$ pore size Millipore filter (Type HA). Following filtration, the filters were rinsed 5 times with cold $5 \%$ TCA with the filtration towers in place, and twice after the towers were removed. The filters were then placed in scintillation vials and dissolved with $1 \mathrm{ml}$ of ethyl acetate, and $5 \mathrm{ml}$ of NEN 963 scintillation cocktail was added. All radioactivity measurements were done on an LKBWallac 1217-Rack Beta scíntillation counter. Sample quench was corrected for using the external standards method. In the long-term toxicity experiments, $\left[{ }^{3} \mathrm{H}\right] \mathrm{TdR}$ radioactivity was measured on a dual label ${ }^{3} \mathrm{H}-{ }^{14} \mathrm{C}$ 
program to separate tracer amounts of ${ }^{14} \mathrm{C}$-pollutant radioactivity which were added to the seawater at the onset of the experiments.

Bacterial cells were quantified with the acridine orange direct count method described by Hobbie et al. (1977). At least 10 fields of 20 or more bacteria were counted on an Olympus BH-2 epifluorescence microscope equipped with an FITC filter set and a mercury burner lamp. Total magnification was 1250 times.

All statistical analyses, including mean comparisons tests, linear regressions, and correlations followed the methods described by Sokol \& Rohlf (1981), with significance levels at $p<0.05$. Unplanned mean comparisons were carried out using the $T$-method. The $T^{\prime}$ method was used for slope comparisons. Instances of heterogenous variances among data to be compared were corrected for by a log transformation.
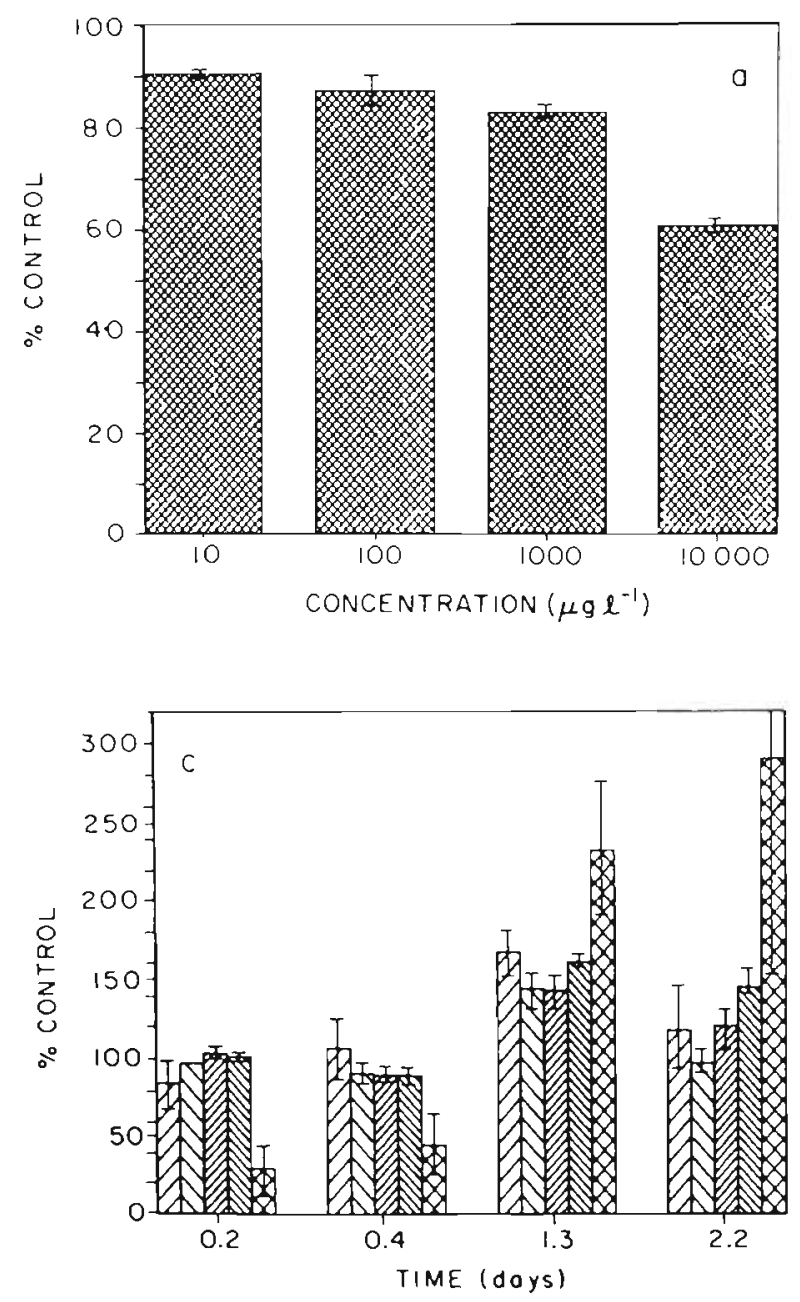

EDA $\mu \mathrm{g}^{-1} \quad$ BII $10 \mu \mathrm{g} \ell^{-1}$

\section{RESULTS}

\section{Acute effects on $\left[{ }^{3} \mathrm{H}\right] \mathrm{TdR}$ incorporation}

Results from acute toxicity experiments using naphthalene, phenanthrene, Kepone, and PCP are depicted in Figs. 1a, 2a, 3a, and 4a, respectively. Bacterial cell numbers and control $\left[{ }^{3} \mathrm{H}\right] \mathrm{TdR}$ incorporation rates were similar for the 4 experiments, as they were all conducted within the same $5 \mathrm{~d}$ period (Table 1). Naphthalene was only mildly inhibitory to bacterial activity; the only significant total $\left[{ }^{3} \mathrm{H}\right] \mathrm{TdR}$ incorporation rate reductions occurred from the 1 and $10 \mathrm{mg} \mathrm{l}^{-1}$ additions (Fig. 1a). The other PAH used in these experiments, phenanthrene, was much more toxic, significantly inhibiting total $\left[{ }^{3} \mathrm{H}\right] \mathrm{TdR}$ incorporation at $100 \mu \mathrm{g} \mathrm{l}^{-1}$ and $1 \mathrm{mg} \mathrm{l}^{-1}$ (Fig. 2a).
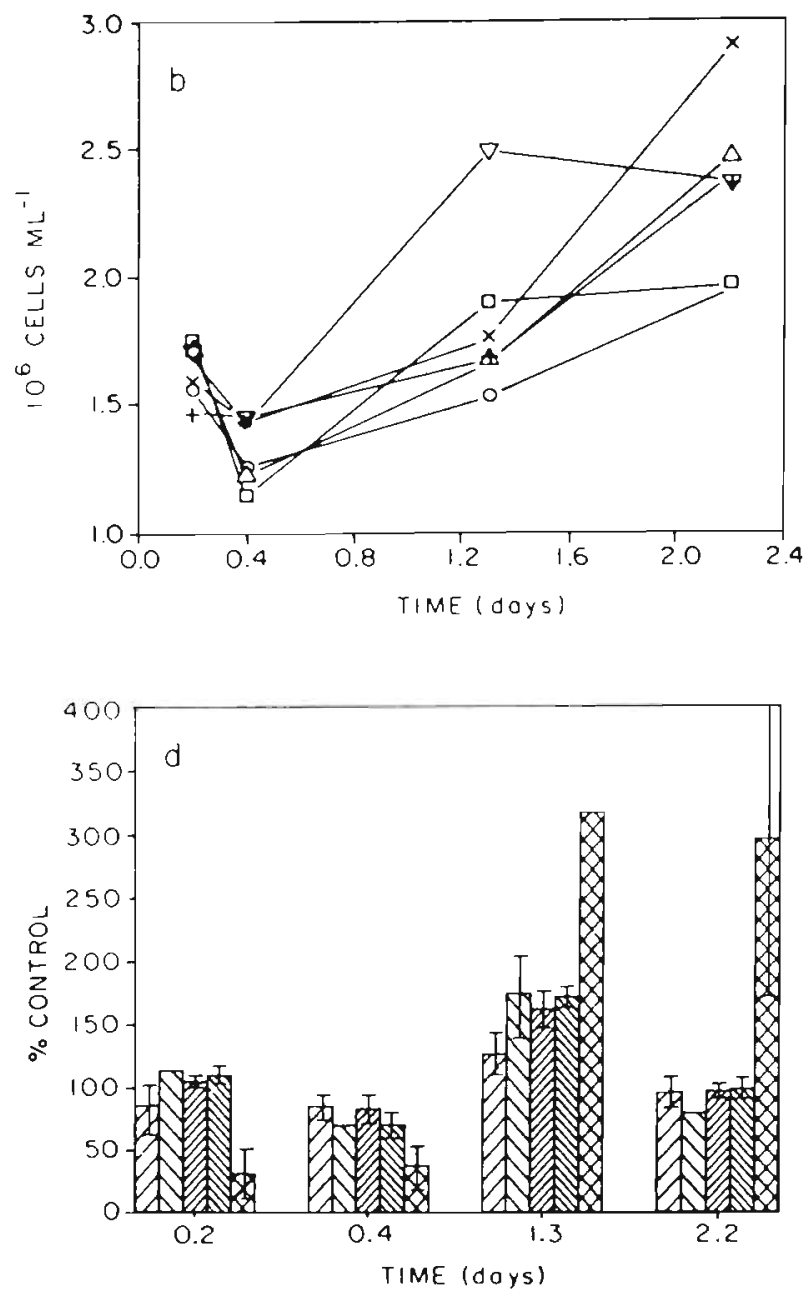

舟 $100 \mu \mathrm{g} \ell^{-1} \quad 10 \mathrm{mg} \ell^{-1}$

Fig. 1. Naphthalene experiments. (a) Acute effects on $\left[{ }^{3} \mathrm{H}\right] \mathrm{TdR}$ incorporation; (b) long-term effects on cell abundance, (ㄷ) control,

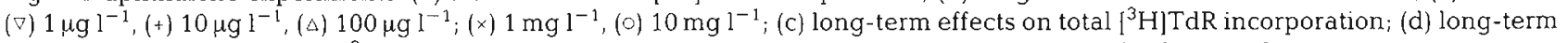
effects on $\left[{ }^{3} \mathrm{H}\right] \mathrm{TdR}$ incorporation per bacterial cell. Vertical bars: \pm 1 standard error of mean 
Toxic effects of chlorinated pesticides were more severe than those of the PAHs. Kepone concentrations of $100 \mathrm{ug} \mathrm{l}^{-1}$ and $1 \mathrm{mg} \mathrm{l}^{-1}$ significantly reduced $\left[^{3} \mathrm{H}\right] \mathrm{TdR}$ incorporation rates (Fig. 3a). PCP effects were similar to those of Kepone, with concentrations of $10 \mu \mathrm{g} \mathrm{l}^{-1}$ to $1 \mathrm{mg} \mathrm{l}^{-1}$ significantly inhibiting $\left[{ }^{3} \mathrm{H}\right] \mathrm{TdR}$ incorporation rates (Fig. 4a).

Linear regression analysis was used to further compare the relative toxicity of these compounds; when \% control response was regressed on compound concentration, all 4 pollutants yielded significant linear regressions (Table 1). A more negative slope is indicative of greater toxicity, Pairwise comparisons showed all slopes were significantly different from each other $(p<0.05)$ except for those of Kepone and PCP. Coeffi- cients of determination $\left(r^{2}\right)$ indicate that a high percentage of the variations in $\left[{ }^{3} \mathrm{H}\right] \mathrm{TdR}$ incorporation relative to controls can be explained by changes in pollutant concentrations (Table 1). The slopes indicate that the toxic responses induced by the 4 pollutants increase in the following order: naphthalene < phenanthrene $<$ pentachlorophenol $=$ Kepone.

\section{Long term effects}

Initial control $\left[{ }^{3} \mathrm{H}\right] \mathrm{HT} \mathrm{dR}$ incorporation rates for all long-term experiments were less than $1 \mathrm{nmol}$ thymidine $\mathrm{l}^{-1} \mathrm{~d}^{-1}$ (data not shown). These rates generally declined as the experiments progressed with the
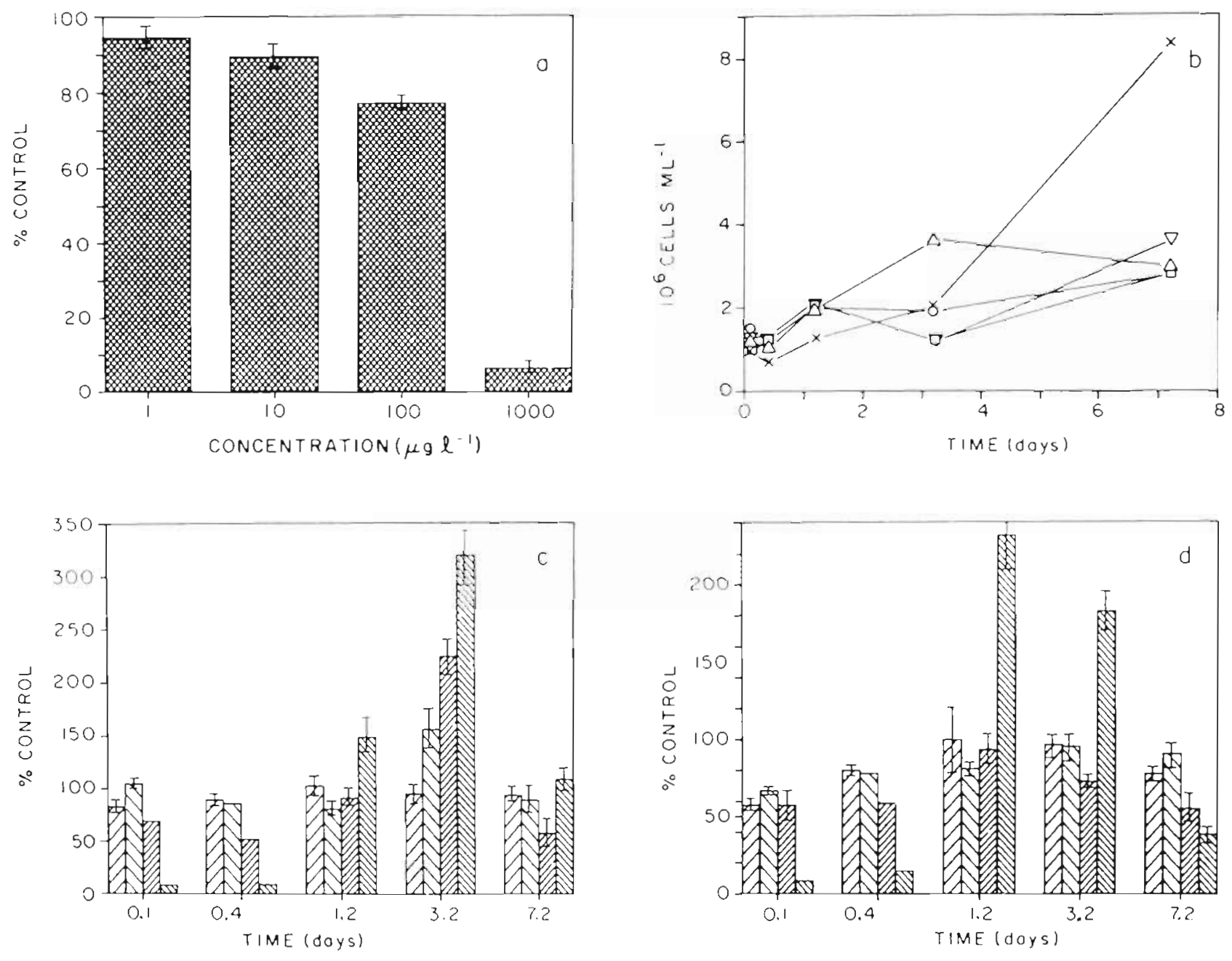

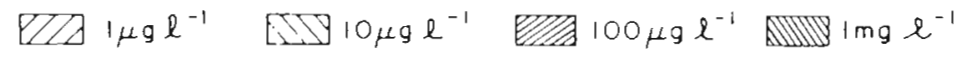

Fig. 3. Kepone experiments. (a) Acute effects on $\left[{ }^{3} \mathrm{H}\right] \mathrm{T} d \mathrm{R}$ incorporation; (b) long-term effects on cell abundance, ( $\square$ ) control, ( $\nabla$ )

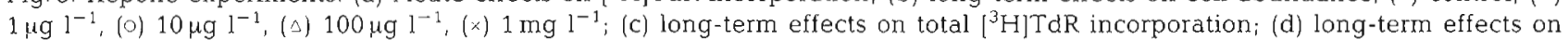
$\left[{ }^{3} \mathrm{H}\right] \mathrm{T} d \mathrm{R}$ incorporation per bacterial cell. Vertical bars: \pm 1 standard error of mean 
exception of the PCP controls which increased to over $7 \mathrm{nmol} \mathrm{l}^{-1} \mathrm{~d}^{-1}$ at $7,2 \mathrm{~d}$. This may have been due to a rapid multiplication of bacteria which could thrive under containment conditions such as the presence of a glass surface.

Long-term naphthalene effects on total $\left[{ }^{3} \mathrm{H}\right] \mathrm{TdR}$ incorporation are shown in Fig. 1c. The only significant effect at any point in the experiment, stimulatory or inhibitory, occurred from the $10 \mathrm{mg} \mathrm{l}^{-1}$ naphthalene addition. Naphthalene at $10 \mathrm{mg} \quad l^{-1}$ significantly reduced the mean total $\left[{ }^{3} \mathrm{H}\right] \mathrm{TdR}$ incorporation at 0.2 and $0.4 \mathrm{~d}$. This concentration later resulted in significantly elevated total $\left[{ }^{3} \mathrm{H}\right] \mathrm{TdR}$ incorporation rates relative to controls at 1.3 and $2.2 \mathrm{~d}$.

More pronounced overall effects were produced by phenanthrene additions. Phenanthrene concentrations of 10,100 , and $500 \mu \mathrm{g} \mathrm{l}^{-1}$ significantly reduced total $\left[{ }^{3} \mathrm{H}\right] \mathrm{TdR}$ incorporation after $0.1 \mathrm{~d}$ (Fig. 2c). At $0.4 \mathrm{~d}$ incorporation rates in the 10 and $100 \mu \mathrm{g} \mathrm{l}^{-1}$ treatments were not significantly different from control rates, and by $3.2 \mathrm{~d}$, the 1,10 , and $100 \mu \mathrm{g} \mathrm{l}^{-1}$ treatments were incorporating $\left[{ }^{3} \mathrm{H}\right] \mathrm{TdR}$ at rates significantly higher than those of the controls

Pesticide effects on bacterial activity were generally more severe initially than those caused by PAH additions. However, seawater bacterial populations exhibited a capacity to recover from acutely toxic concentrations of both Kepone and PCP as experiments progressed. Kepone at $100 \mu \mathrm{g} \mathrm{l}^{-1}$ and $1 \mathrm{mg} \mathrm{l}^{-1}$ significantly inhibited total $\left[{ }^{3} \mathrm{H}\right] \mathrm{TdR}$ incorporation for $0.4 \mathrm{~d}$ after addition (Fig. 3C). By $1.2 \mathrm{~d}$, bacterial populations exposed to both these concentrations had recovered, with the $1000 \mu \mathrm{g} \mathrm{l}^{-1}$ treatments incorporating $\left[{ }^{3} \mathrm{H}\right] \mathrm{TdR}$ at a mean rate significantly higher than that of the
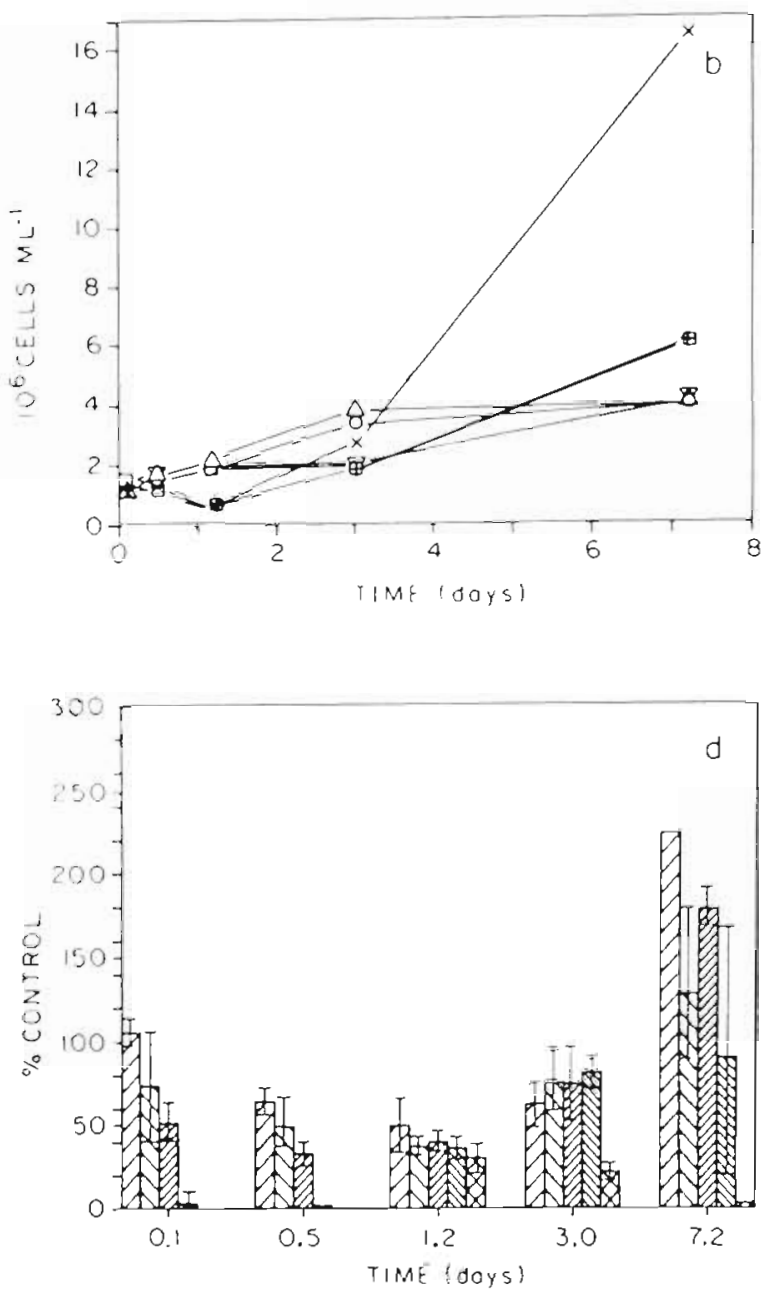

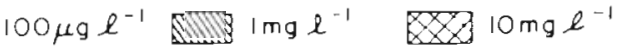

Fig. 4. PCP experiments. (a) Acute effects on $\left.\int^{3} \mathrm{H}\right] \mathrm{T} d \mathrm{R}$ incorporation; (b) long-term effects on cell abundance, ( $(\mathrm{)})$ control, ( 7 ) $1 \mu \mathrm{g}$ $1^{-1}$, ( ) $10 \mu \mathrm{g} \mathrm{l}^{-1}$, (c) $100 \mathrm{~kg} \mathrm{l}:$, (x) $1 \mathrm{mg} \mathrm{l}^{-1},(+) 10 \mathrm{mg} \mathrm{l}^{-1}$ (c) long-term effects on total $\left[^{3} \mathrm{H}\right] \mathrm{TdR}$ incorporation; (d) long-term effects on $\left[{ }^{3} \mathrm{H}\right] \mathrm{T} d \mathrm{R}$ incorporation per bacterial cell. Vertical bars: \pm 1 standard error of mean 
controls. By $3.2 \mathrm{~d}$, total $\left[{ }^{3} \mathrm{H}\right] \mathrm{TdR}$ incorporation by the

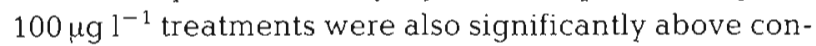
trol rates. This was followed by a sharp reduction in activity by both the $100 \mathrm{\mu g} \mathrm{l}^{-1}$ and $1 \mathrm{mg} \mathrm{l}^{-1}$ treatments at $7.2 \mathrm{~d}$, with none of the Kepone concentrations resulting in total $\left[{ }^{3} \mathrm{H}\right] \mathrm{TdR}$ incorporation rates significantly different from control values.

The results from the long-term PCP experiments are depicted in Fig. 4. Only the 1 and $10 \mathrm{mg} \mathrm{l}^{-1}$ concentrations were shown to significantly inhibit total $\left.{ }^{3} \mathrm{H}\right] \mathrm{TdR}$ incorporation at any time during the experiment. However, apparent effects occurred at all concentrations tested (Fig. 4c). These non-statistically significant effects may have been masked by an excessive amount of variability in the data. PCP at $10 \mathrm{mg} \mathrm{l}^{-1}$ was the only concentration that resulted in a mean total $\left[{ }^{3} \mathrm{H}\right] \mathrm{TdR}$ incorporation rate significantly different from the controls at 3 and $7.2 \mathrm{~d}$. None of the PCP concentrations tested significantly stimulated total $\left[{ }^{3} \mathrm{H}\right] \mathrm{TdR}$ incorporation at any time, although there was an apparent stimulation by $1 \mu \mathrm{g} \mathrm{l}^{-1}$ PCP at $7.2 \mathrm{~d}$ of both total and per cell rates.

\section{DISCUSSION}

Bacterioplankton populations in this study were not only capable of surviving initially toxic pollutant concentrations, but were often able to grow at rates significantly higher than controls after an adaptation period. Recoveries from $10 \mathrm{mg} \mathrm{l}^{-1}$ naphthalene and $100 \mu \mathrm{g} \mathrm{l}^{-1}$ phenanthrene may have been aided by the abiotic loss of these compounds. Bauer \& Capone (1985) observed similar stimulations of $\left[{ }^{14} \mathrm{C}\right.$ lglucose metabolism by sediment microorganisms after several day exposures to $100 \mathrm{ppm}$ concentrations of anthracene, naphthalene, and DDT. Griffiths et al. (1981) demonstrated that although glucose and glutamate uptake by Arctic bacterioplankton was initially inhibited by $0.1 \%$ crude oil, these populations could recover within a few days. Observed adaptations of bacterial populations to toxic substances may have been caused by a selection for resistant bacteria within the population. It is often the case that an area contaminated with petroleum hydrocarbons will consist of higher percentages of culturable species capable of utilizing these pollutants (Walker \& Colwell 1975, Atlas 1981). The time lag before recovery from initially toxic growth effects which occurred in several instances may have resulted from the time required to induce oxygenase enzymes capable of aerobically detoxifying the specific hydrocarbon (Perry 1979).

The chlorinated pesticides used in this study were more acutely toxic to bacterioplankton communities than the PAHs tested. This corresponds with an increase in octanol-water partition coefficients, which are 3.35 for naphthalene, 4.46 for phenanthrene, and 5.01 for PCP (data on Kepone are not available). The presence of chlorine on an organic molecule usually makes it less chemically reactive toward oxygen (Chakrabarty 1982). Thus, the aerobic detoxification and biodegradation of a chlorinated compound is often a relatively slow process. The acute responses of bacterial populations exposed to Kepone and those exposed to PCP were very similar to one another. In fact, the regression coefficients of \% control response versus compound concentration were virtually identical for both compounds (Table 1). Acute exposure to $10 \mu \mathrm{g} \mathrm{l}^{-1} \mathrm{PCP}$ significantly reduced $\left[{ }^{3} \mathrm{H}\right] \mathrm{TdR}$ incorporation by $10 \%$, the lowest significantly inhibiting concentration $(p<0.05)$ of the 4 pollutants tested in the acute effects studies. Although a high degree of variability in the long-term experiments appeared to mask apparent toxic effects of PCP, initial effects resulting from Kepone and PCP exposure appear quite similar (Figs. 3 and 4). Bacterioplankton populations exposed to Kepone recovered somewhat faster than those subjected to PCP, although this recovery was short lived. The approximately equal responses of bacterioplankton to additions of Kepone and PCP might be related to the similar chlorine content of each molecule, 72 and $67 \%$ chlorine per mole of Kepone and PCP, respectively. The relative effects of these pesticides observed here differ somewhat from those of Mahaffey et al. (1982), who reported results indicating that mixed cultures of estuarine bacteria were slightly more inhibited by $1 \mathrm{mg} \mathrm{l}^{-1}$ Kepone than by $2.7 \mathrm{mg} \mathrm{l}^{-1} \mathrm{PCP}$. In the same study it was found that $2 \mathrm{mg} \mathrm{l}^{-1}$ reduced the total viable counts of estuarine bacteria to $33 \%$ of controls whereas in the present study total $\left[^{3} \mathrm{H}\right] \mathrm{TdR}$ incorporation was reduced to $6 \%$ of controls by $1 \mathrm{mg} \mathrm{l}^{-1}$ Kepone.

The greater toxicity of phenanthrene relative to naphthalene agrees with the results of Calder \& Lader (1976), who found that the sensitivity of marine bacteria to PAHs increases when exposed to compounds of higher molecular weight and lower solubility. This is also related to the higher octanol-water coefficient of phenanthrene (see above), which is commonly associated with toxicity. Phenanthrene at $100 \mu \mathrm{g} \mathrm{l^{-1 }}$, which reduced $\left[{ }^{3} \mathrm{H}\right] \mathrm{TdR}$ incorporation by $19 \%$ in the acute effects experiments of the present study, had no significant effect on glucose uptake by microbial populations from a Tennessee reservoir (Sayler et al. 1979). Bauer \& Capone (1985) assessed the effects of naphthalene, anthracene, DDT, and $\mathrm{PCP}$ on $\left[{ }^{3} \mathrm{H}\right] \mathrm{TdR}$ incorporation by sediment microorganisms from a salt marsh near the sampling site used in the present study. Comparisons of their results to those reported here suggest that sediment bacteria are more tolerant to inputs of hazardous pollutants than bacteria living in the water 
column. In the present study, concentrations of $10 \mathrm{mg}$ $1^{-1}$ naphthalene and $1 \mathrm{mg} \mathrm{1^{-1 }}$ PCP yielded substantial reductions in $\left[{ }^{3} \mathrm{H}\right] \mathrm{TdR}$ incorporation by bacterioplankton. However, sediment bacteria were unaffected by $10 \mathrm{mg} \mathrm{l}^{-1}$ naphthalene and were capable of incorporating $\left[{ }^{3} \mathrm{H}\right] \mathrm{T} d \mathrm{R}$ at a rate $85 \%$ that of controls in the presence of $1 \mathrm{mg} \mathrm{l}^{-1} \mathrm{PCP}$. The greater tolerance of organic pollutants by sediment bacteria relative to those inhabiting the water column has not been studied in detail. Possible explanations include a higher availability of organic nutrients in sediments, greater resistance brought on by previous exposure to higher concentrations of organic pollutants, or binding of pollutants to sediment particles (Karickhoff et al. 1979), thus resulting in reduced concentrations in interstitial waters available for microbiological uptake.

There were several instances during the long-term effects experiments where certain pollutant additions appeared to reduce the $\left[{ }^{3} \mathrm{H}\right] \mathrm{TdR}$ incorporation rate per cell substantially more than the total $\left[{ }^{3} \mathrm{H}\right] \mathrm{TdR}$ incorporation rate e.g., $100 \mathrm{\mu g} \mathrm{l}^{-1}$ phenanthrene at $3.2 \mathrm{~d}$ and $10 \mu \mathrm{g} \mathrm{l}^{-1}$ Kepone at $0.1 \mathrm{~d}$. Effects on per cell rates reflect the alteration of individual cell growth whereas effects on total $\left[{ }^{3} \mathrm{H}\right] \mathrm{TdR}$ incorporation are representative of the response of the entire bacterial population. These results may be due to pollutant inhibition of bacterial grazers, although this evidence is circumstantial. The differential effects on total and per cell rates at $3.2 \mathrm{~d}$ by $100 \mu \mathrm{g}^{-1}$ phenanthrene were also accompanied by a sharp increase in bacterial cell abundance. Also, the highest final cell yields in all the long-term experiments were at either the highest or next to highest concentrations tested.

Past laboratory studies indicate that other planktonic organisms may be less tolerant of toxic substances than the bacteria studied here. O'Connors et al. (1978) reported that $\mathrm{PCB}$ concentrations of 1 to $10 \mu \mathrm{g} \mathrm{l^{-1 }}$ reduced phytoplankton size and biomass in natural estuarine samples. $\mathrm{LC}_{50}$ values for naphthalene were $140 \mathrm{ug} \mathrm{l}^{-1}$ for ctenophores exposed for $24 \mathrm{~h}$ and $290 \mathrm{\mu g}$ $\mathrm{l}^{-1}$ for copepods exposed for $48 \mathrm{~h}$ (Lee \& Anderson 1977). Reported $\mathrm{EC}_{50}$ values determined from growth rates of marine unicellular algae cultures exposed to Kepone for $7 \mathrm{~d}$ ranged from 350 to $600 \mathrm{\mu g} \mathrm{l}^{-1}$ (Walsh et al. 1977). Schauerte et al. (1982) found dramatic population shifts in a microcosm situated in a natural pond and dosed with $1 \mathrm{ppm}$ PCP, including a decline in Daphnia populations to zero in $3 d$, a decrease in cyanobacteria and diatoms, and an increase in flagellates and bacteria. In the present study, bacterioplankton populations exposed to initially toxic levels of naphthalene, phenanthrene, and Kepone showed signs of recovery after $1 \mathrm{~d}$, whereas apparent resistance to $1 \mathrm{mg} \mathrm{l^{-1 }}$ of PCP was observed by the third day of the experiment. Developed resistance to organochlorine pollutants by microflagellate and diatom cultures has usually been accomplished over a period of weeks to months (Duncan 1983). Thus, bacteriovores may have been severely inhibited at pollutant concentrations at which the bacteria were either not affected or could recover from within days, allowing the bacteria to grow unchecked by bacterivory. It should be noted that the possible relationship of increased bacterial activity due to effects on grazers is speculative, and factors such as resistance, bottle effects, and usage of the added compound as a carbon source may have also played a role in allowing bacterial numbers to increase. Hudak (1985) and Hudak et al. (1988) found that at this location microbial mineralization of the PAHs was fairly rapid (ca 10's of \% per day), but that of PCP was $<1 \%$ $\mathrm{d}^{-1}$, with incorporation into biomass generally much less than mineralization. Therefore, growth at the expense of the pollutants was probably not a major factor in most of the treatments, except possibly at the higher PAH concentrations. The possible effects of organic pollutants on eucaryotic bacterivores require further research.

The pollutant concentrations used in this study are generally much higher than those measured in natural aquatic systems, usually being in the $\mathrm{ng} \mathrm{1}^{-1}$ range (Gschwend et al. 1982, Readman et al. 1982, Burris \& Huggett 1984). However, there have been concentrations measured in several polluted areas approaching those used here. Hites \& Biemann (1972) measured naphthalene concentrations as high as $3.4 \mu \mathrm{g} l^{-1}$ in the Charles River, Boston. Acheson et al. (1976) reported concentrations of individual PAHs in the low $\mu \mathrm{g} 1^{-1}$ range. The June, 1979 blowout of the Ixtoc I oil well, off the coast of Mexico, resulted in dissolved concentrations of naphthalene, phenanthrene, and dibenzothiophenes of about $50 \mu \mathrm{g} \mathrm{I}^{-1}$ near the well (Boehm \& Fiest 1980). Measured concentrations of PCP in the Williamette River, Oregon, were as high as $0.7 \mu \mathrm{g} \mathrm{l^{-1 }}$ (Buhler et al. 1973). Goto (1971) found PCP at levels of 1 to $10 \mu \mathrm{g} \mathrm{l}^{-1}$ in rivers of southwest Japan. PCP concentrations as high as $7.3 \mu \mathrm{g} \mathrm{I}^{-1}$ have been recorded for numerous fresh and marine waters of southern British Columbia (Environment Canada 1979).

Considering the results of the present study and the past reported environmental PAH concentrations discussed above, it is unlikely that naphthalene would have a major impact on marine bacterioplankton communities. Concentrations of $100 \mu \mathrm{g} \mathrm{l}^{-1}$ naphthalene were not inhibitory to bacterial $\left[{ }^{3} \mathrm{HJTdR}\right.$ incorporation, although naphthalene could threaten microbial communities inhabiting marine sediments, where higher levels of PAHs are known to accumulate (Johnson et al. 1985). Phenanthrene could conceivable reduce the activity of water column bacteria following a petroleum spill, as a concentration of $10 \mu \mathrm{g} \mathrm{l}^{-1}$ was shown to 
significantly reduce $\left[{ }^{3} \mathrm{H}\right] \mathrm{TdR}$ incorporation (Fig. 2c). However, microbial degradation may provide a removal mechanism for both phenanthrene and naphthalene in the marine water column, with microbes in certain areas degrading these substances as rapidly as $40 \%$ or more per day (Hudak 1985. Hudak et al. 1988).

The chlorinated pesticides used in this study were much more toxic than the PAHs studied here. Because of extremely low concentrations of Kepone measured in the water relative to the sediments of the James River (Burris \& Huggett 1984) it is likely that the most severe impacts on microbial communities are felt in the sediment. Adding to the threat of Kepone is its high resistance to biodegradation (Orndorff \& Colwell 1980, Skaar et al. 1981). Of the 4 organic pollutants studied here, PCP probably holds the greatest potential for altering marine bacterioplankton communities. The chemical behavior of PCP, including its relatively high solubility, low volatility, and relatively low tendency to attach to suspended particles (Lee et al. 1982) amplifies its potential threat to bacterioplankton populations.

Acknowledgements. We thank D. Capone, D. Young, and J. Bauer for their suggestions during this study. This investigation was funded in part by grant no. 004/85A/023 from the Hudson River Foundation, National Science Foundation grant OCE-8410074, the Women's Seaman's Friend Society of Connecticut, and Sigma Xi.

\section{LITERATURE CITED}

Acheson, M.A., Harrison, R., Perry, R., Wellings, R. A. (1976). Factors affecting the extraction and analysis of polynuclear aromatic hydrocarbons in water. Wat. Res. 10: 207-212

Alexander, S.K., Schwarz, J.R. (1980). Short-term effects of South Louisiana and Kuwait crude oils on glucose utilization by marine bacterial populations. Appl. environ. Microbiol. 40: 341-345

Atlas, R. M. (1981). Microbial degradation of petroleum hydrocarbons: an environmental perspective. Microbiol. Rev. 45: 180-209.

Bauer, J.E., Capone, D. G. (1985). Effects of four aromatic organic pollutants on microbial glucose metabolism and thymidine incorporation in marine sediments. Appl. environ. Microbiol. 49: 828-835

Blakemore, R.P., Carey, A.E. (1978). Effects of polychlorinated biphenyls on growth and respiration of heterotrophic marine bacteria. Appl. environ. Microbiol. 35: 329-336

Boehm, P.D., Fiest, D. L. (1980). Surface water column transport and weathering of petroleum hydrocarbons during the IXTOC-I blowout in the Bay of Campeche and their relation to surface oil and microlayer compositions. In: Proc. Symposium on preliminary results from the September, 1979 Researcher/Pierce IXTOC-I cruise, NOAA, Washington, D. C.

Buhler, D. R., Rasmussen, M. E., Nakaue, H. S. (1973). Occurrence of hexachlorophene and pentachlorophenol in sewage and water. Environ. Sci. Technol. 7. 929-934
Brown, M. P., Werner, M. B., Sloan, R. J. (1985). Polychlorinated biphenyls in the Hudson River. Environ. Sci. Technol. 19: 656-661

Burris, D. R., Huggett, R. J. (1984). Evaluation of elutriate test parameters for an organic hydrophobic pollutant, Kepone. Environ. Pollut. Ser. B 8: 63-69

Calder, J. A., Lader, J.H. (1976). Effect of dissolved aromatic hydrocarbons on the growth of marine bacteria in batch culture. Appl. environ. Microbiol. 32: 95-101

Chakrabarty, A. M. (1982). Genetic mechanism in the dissimilation of chlorinated compounds. In: Chakrabarty, A. M. (ed.) Biodegradation and detoxification of environmental pollutants. CRC Press Inc., Boca Raton, Fla., p. 127-139

Connell, D.W. (1982). An approximate petroleum hydrocarbon budget for the Hudson Raritan Estuary-New York. Mar. Pollut. Bull. 13: 89-93

Ducklow, H.W. (1983). Production and fate of bacteria in the oceans. BioScience 33: 494-501

Duncan, B.T (1983). The development on the laboratory of resistance to PCB by two marine phytoplankters. M.S. thesis, State University of New York, Stony Brook

Dzombak, D. A., Luthy, R. G. (1984). Estimating adsorption of polycyclic aromatic hydrocarbons on soils. Soil Sci. 137: 5-12

Environment Canada (1979). Monitoring environmental contamination from chlorophenol contaminated wastes generated in the wood preservation industry. Regional program report 79-24, Environ. Protection Service, West Vancouver, British Columbia

Fenchel, T (1982). Ecology of heterotrophic microflagellates. IV. Quantitative occurrence and importance as bacterial consumers. Mar. Ecol. Prog. Ser. 9: 35-42

Ferguson, R. L., Buckley, E. N., Palumbo, A.V (1984). Response of marine bacterioplankton to differential filtration and confinement. Appl. environ. Microbiol. 47: 49-55

Fuhrman, J. A., Azam, F. (1982). Thymidine incorporation as a measure of heterotrophic bacterioplankton production in marine surface waters: evaluation and field results. Mar. Biol. 66: 109-120

Fuhrman, J.A., McManus, G.B. (1984). Do bacteria-sized marine eukaryotes consume significant bacterial production? Science 224: 1257-1260

Goto, M. (1971). Organochlorine compounds in the environment in Japan. In: Tahori, A.S. (ed.) International Symposium on Pesticide Terminal Residues. Pure and Appl. Chemistry Suppl. Butterworths, London, p. 105-110

Griffiths, R. P., McNamara, T. M., Caldwell, B. A., Morita, R. Y (1981). Field observations on the acute effect of crude oil on glucose and glutamate uptake in samples collected from Arctic and Subarctic waters. Appl. environ. Microbiol 41: 1400-1406

Gschwend, P. M., Zafiriou, O.C., Mantoura, R. F. C., Schwartzenbach, R.P., Gagosian, R. B. (1982). Volatile organic compounds at a coastal site. 1. Seasonal variations. Environ. Sci. Technol, 16: 31-38

Hagstrom, A., Larsson, U., Horstedt, P., Normark, S. (1979). Frequency of dividing cells, a new approach to the determination of bacterial growth rates in aquatic environments. Appl environ. Microbiol. 37: 805-812

Hites, R. A., Biemann, K. (1972). Water pollution: organic compounds in the Charles River, Boston. Science 178: $158-160$

Hobbie, J. E., Daley, R. J, Jasper, S. (1977). Use of Nuclepore filters for counting bacteria by fluorescence microscopy. Appl. environ. Microbiol. 33: 1225-1228

Hoffman, E. J., Mills, G. L., Latimer, J. S., Quinn, J. G. (1984). Urban runoff as a source of polycyclic aromatic hydrocarbons to coastal waters. Environ. Sci. Technol. 18: 580-587 
Hudak, J.P. (1985). Interactions between four organic pollutants and natural assemblages of marine bacterioplankton. M.S. thesis, S.U.N.Y at Stony Brook, Stony Brook, New York

Hudak, J.P., McDaniel, J., Lee, S. H., Fuhrman, J. A. (1988). Mineralization of aromatic hydrocarbons by estuarine microorganisms: variations with season, location, and bacterioplankton production. Mar. Ecol. Prog. Ser. 47. 97-102

Huggett, R. J., Bender, M.E. (1980). Kepone in the James River. Environ. Sci. Technol. 14: 918-923

Jannasch, H. W., Jones, G.E. (1959). Bacterial populations in seawater as determined by different methods of enumeration. Limnol. Oceanogr. 4: 128-139

Johnson, A. C., Larsen, P. F., Gadbois, D. F., Humason, A. W (1985). The distribution of polycyclic aromatic hydrocarabons in the surficial sediments of Penobscot Bay (Maine, USA) in relation to possible sources and to other sites worldwide. Mar. environ. Res. 15: 1-16

Jonas, R. B., Gilmour, C. C., Stoner, D. L., Weir, M. M.; Tuttle, J.H. (1984). Comparison of methods to measure acute metal and organometal toxicity to natural aquatic microbial communities. Appl. environ. Microbiol. 43: 1419-1424

Karickhoff, S. W., Brown, D.S., Scott, T. A. (1979). Sorption of hydrophobic pollutants on natural sediments. Wat. Res. 13 $241-248$

Lee, R. F., Anderson, J.W (1977). Fate and effect of naphthalenes: controlled ecosystem pollution experiment. Bull. mar. Sci. 27: 127-134

Lee, R. F., Hinga, K., Almquist, G. (1982). Fate of radiolabeled polycyclic aromatic hydrocarbons and pentachlorophenol in enclosed marine ecosystems. In: Grice, G. D., Reeve, M. (eds.) Marine mesocosms. Springer Verlag, New York, p. 123-135

Mahaffey, W. R., Pritchard, P.H., Bourquin, A.W (1982) Effects of Kepone on growth and respiration of several estuarine bacteria. Appl. environ. Microbiol. 43 $1419-1424$

Meyer-Reil, L.-A. (1977). Bacterial growth rates and production. In: Rheinheimer, G. (ed.) Microbial ecology of a brackish water environment. Springer-Verlag. Berlin p. $223-236$
Meyling, A. H., Pitchford, R.J. (1966). Physiochemical properties of substances used as molluscicides. Bull. World Health Org. 34: 141-145

O'Connors, H. B., Wurster, C.F., Powers, C. D., Biggs, D. C. Rowland, R. G. (1978). Polychlorinated biphenyls may alter marine trophic pathways by reducing phytoplankton size and production. Science 201: 737-739

Orndorff, S. A., Colwell, R. R. (1980). Microbial transformation of Kepone. Appl. environ. Microbiol. 39: 398-406

Perry, J. J. (1979). Microbial cooxidations involving hydrocarbons. Microbiol. Rev. 43: 59-72

Readman, J.W., Mantoura, R. F. C., Rhead, M. M., Brown, L. (1982). Aquatic distribution and heterotrophic degradation of polycyclic aromatic hydrocarbons (PAH) in the Tamar estuary. Estuar. coast. Shelf. Sci. 14: 369-389

Sayler, G. S., Lund, L. C., Shiaris, M. P., Sherril T. W., Perkins, R.E. (1979). Comparative effects of Aroclor 1254 (polychlorinated biphenyls) and phenanthrene on glucose uptake by freshwater microbial populations. Appl. environ. Microbiol. 37: 878-885

Schauerte, W., Lay, J. P., Klein, W., Korte, F. (1982). Influence of 2,4,6-trichlorophenol and pentachlorophenol on the biota of aquatic systems. Chemosphere 11:71-79

Skaar, D. R., Johnson, B. T., Jones, J. R., Huckins, J. N. (1981). Fate of Kepone and mirex in a model aquatic environment: sediment, fish, and diet. Can. J. Fish. Aquat. Sci. 38: 931-938

Sokol, R. R., Rohlf, F. J. (1981). Biometry. W. H. Freeman and Company, New York

Verschueren, K. (1983). Handbook of environmental data on organic chemicals. Van Nostrand Reinhold Company, Inc., New York

Walker, J. D., Colwell, R. R. (1975). Some effects of petroleum on estuarine and marine microorganisms. Can. J. Microbiol. 21: 305-313

Walsh, G.E., Ainsworth, K.A., Wilson, A.J. (1977). Toxicity and uptake of Kepone in marine unicellular algae Chesapeake Sci. 18: 222-223

Williams, P. J. leB. (1981). Incorporation of microheterotrophic processes into the classic paradigm of the planktonic food web. Kiel. Meeresforsch., Sonderh. 5: 1-28 